\title{
Effects of Oxidized Glutathione, Bovine Serum Albumin, Cysteine and Lycopene on the Quality of Frozen-Thawed Ram Semen
}

\author{
O. UYSAL, M. N. BUCAK
}

Ankara University, Faculty of Veterinary Medicine, Department of Reproduction and Artificial Insemination, Ankara, Turkey

Received February 28, 2007

Accepted June 5, 2007

\begin{abstract}
Uysal O., M. N. Bucak: Effects of Oxidized Glutathione, Bovine Serum Albumin, Cysteine and Lycopene on the Quality of Frozen-Thawed Ram Semen. Acta Vet. Brno 2007, 76: 383-390.

Free radicals are known to be involved in lipid peroxidation as well as DNA and sperm membrane damages that may lead to decreased sperm motility or cell death. The balance between free radical production and their detoxification may be an important factor in sperm survival and function before, during and after cryopreservation. The aim of this study was to determine the effects of the addition of the antioxidants of oxidized glutathione (GSSG), bovine serum albumin (BSA), cysteine and lycopene to freezing media on the post-thawing sperm characteristics, including motility, morphology, acrosome integrity, viability and membrane integrity. A total number of 42 ejaculates were collected using the artificial vagina from 4 Akkaraman rams and 10 replicates of the ejaculates were diluted with a Tris-based extender containing additives and no additives as control.

GSSG $(5 \mathrm{mM})$, BSA $(20 \mathrm{mg} / \mathrm{ml})$, cysteine $(10 \mathrm{mM})$ and lycopene $(800 \mu \mathrm{g})$ showed more positive effects than other concentrations of the supplements and controls in protecting sperm characteristics after the freezing-thawing process $(P<0.001)$.

Many aspects of sperm protection, e.g. sperm motility, viability and membrane stabilisation of the sperm cells during relative cryopreservation, are the key factors in determining the preservation of sperm function. The results of this study provide a new approach to the cryopreservation of sperm from rams and related breeds, and thereby contribute to the improvement of these breeds for the world sheep industry.
\end{abstract}

Antioxidants, ram semen, freezing, extender

Frozen-thawed ram sperm demonstrates serious cryopreservation damage and thus a highly reduced fertilizing capacity (Maxwell and Watson 1996). Cervical artificial insemination, in which frozen semen is used, is limited by low fertility rates in sheep (Salamon and Maxwell 1995). For this reason, it requires application of the intrauterine technique to achieve an acceptable result in sheep fertility. On the other hand, alternative methods for the freezing of ram sperm cells require further improvements regarding membrane damage (King et al. 2004).

Sperm cells have a high content of unsaturated fatty acids in their membranes and they lack a significant cytoplasmic component containing antioxidants. Therefore, sperm cells are highly susceptible to lipid peroxidation (LPO) by free radicals such as hydrogen peroxide, superoxide anion, and hydroxyl radical, which lead to the structural damage of sperm membranes during the freezing-thawing process (Sinha et al. 1996). The freezing process produces physical and chemical stress on the sperm membrane which in turn reduces sperm viability and fertilizing ability. The cold shock of sperm cells during the freezing-thawing process is associated with oxidative stress induced by free radicals (Salvador et al. 2006; Sanacka and Kurpisz 2004). These free radicals are eliminated by antioxidant systems. Antioxidants play an important role in scavenging free radicals

Address for correspondence:

Assoc. Prof Dr. Ongun Uysal, DVM, PhD

Ankara University, Faculty of Veterinary Medicine

Department of Reproduction and Artificial Insemination

06110 Diskapi, Ankara, TURKEY
Phone: +903123170315406

Fax: + 903123186304

E-mail: onuysal@veterinary.ankara.edu.tr

http://www.vfu.cz/acta-vet/actavet.htm 
which may cause lipid peroxidation of sperm plasma membranes (Baumber et al. 2000). The addition of antioxidants is well known to improve the viability and motility of liquid storage or cryopreserved ram sperm cells (Baumber et al. 2005; Maxwell and Stojanov 1996).

Evidence has shown that the rapid decline in intracellular GSH concentrations, that occurs during the incubation of spermatozoa under aerobic conditions, is not associated with an increase in GSSG concentrations (Bilodeau et al. 2000). This phenomenon can be caused by thiol reacting with other molecules and occurring as hidden GSH (Bernard and Balasubramanian 1995). The fact that proteins bind with glutathione and form mixed disulphides (protein-S-S-glutathione) is well known. These disulphides can protect proteins against oxidative insult (Luberda 2005).

According to Bilodeau et al. (2001), thiols such as glutathione and cysteine, prevented the loss of sperm motility in frozen-thawed bull semen. Cysteine is a low molecular weight amino acid containing thiol; it is a precursor of intracellular glutathione biosynthesis, and increases the GSH level. Funahashi and Sano (2005) and Szczesniak-Fabianczyk et al. (2006) reported that a semen extender with cysteine improved the viability, chromatin structure and membrane integrity of boar sperm cells during liquid preservation.

One of the most important features of bovine serum albumin (BSA) is known as the elimination of free radicals generated by oxidative stress, and the protection of membrane integrity of sperm cells from heat shock during freezing-thawing of canine semen (Uysal et al. 2005). Matsuoka et al. (2006) reported that BSA can be substituted for egg-yolk in the ram semen diluent, and that it enhances the motility and viability of ram sperm cells following the freezing-thawing process.

Carotenoids, such as beta-carotene and lycopene, are important components of antioxidant defense against lipid peroxidation in living cells (Agarwal et al. 2005). Lycopene, an aliphatic hydrocarbon, has received particular attention as a result of studies indicating that it has highly efficient antioxidant and free radical scavenging capacity (Türk et al. 2006).

\section{Materials and Methods}

Animals and semen collection

Semen samples from 4 mature Akkaraman rams ( 3 and 4 years of age) were used in this study. The animals were housed at the Education Research and Practice Farm of Ankara University, Faculty of Veterinary Medicine, and maintained using conventional feeding, housing and lighting conditions.

A total number of 42 ejaculates were collected from the rams using an artificial vagina twice a week during the breeding season (autumn to early winter). Semen samples were pooled to eliminate individual differences. Ten pooled ejaculates were included in the study. For the purpose of collecting ejaculates, rams were penned with ewes in oestrus, in the presence of a handler with an artificial vagina (Ollero et al. 1996; Paulenz et al. 2002). The ejaculates were evaluated and accepted for evaluation if the following criteria were met: volume varying between 0.75 - $2 \mathrm{ml}$; sperm concentration of $3 \times 10^{9} \mathrm{sperm} / \mathrm{ml}$; the motile sperms percentage higher than $70 \%$ and less than $10 \%$ abnormal sperm in total.

Semen processing and evaluation

All the reagents used were analytical grade (Sigma, St. Louis). Since the additives (Sigma Chemical Co.), GSSG, BSA, cysteine, and lycopene were available in different purities, the following samples of stated catalogue designations were used throughout the study: GSSG, G-2140; BSA, Sigma Fraction V, A-9647; cysteine, C-7352; lycopene, L-9879. In this trial, a Tris-based extender (CTR) was used (Tris $3.63 \mathrm{~g} / 100 \mathrm{ml}$, fructose $0.50 \mathrm{~g} / 100 \mathrm{ml}$, citric acid $1.99 \mathrm{~g} / 100$ $\mathrm{ml}$, egg yolk $10 \mathrm{ml} / 100 \mathrm{ml}$, penicillin $100.000 \mathrm{iu} / 100 \mathrm{ml}$, streptomycin $100 \mathrm{mg} / 100 \mathrm{ml}-\mathrm{pH} 6.8,300 \mathrm{mOsm}$ ) for all the ejaculates. Each pooled ejaculate was split into 13 equal aliquots and diluted with the CTR extender with GSSG $(5,10$ or $20 \mathrm{mM})$, BSA $(5,10$ or $20 \mathrm{mg} / \mathrm{ml})$, cysteine $(5,10$ or $20 \mathrm{mM})$, lycopene $(800,1600$ or $3200 \mu \mathrm{g} / \mathrm{ml})$ or no additives (controls) for a total of 13 experimental semen groups $\left(37^{\circ} \mathrm{C}\right)$ at a final concentration of $4 \times 108$ spermatozoa per $\mathrm{ml}$. Sperm concentrations were determined with the aid of a hemocytometer (Smith and Mayer 1955). Diluted semen samples were drawn into $0.25 \mathrm{ml}$ French straws and frozen in liquid nitrogen vapour $\left(-100\right.$ to $\left.-120^{\circ} \mathrm{C}\right)$ and then stored in liquid nitrogen $\left(-196^{\circ} \mathrm{C}\right)$. Post-thawing sperm motility, morphologic sperm abnormalities, acrosome damages, viability and the functional membrane integrity of sperm cells were determined in samples.

Progressive motility was assessed using a phase-contrast microscope $(\times 100$ magnification $)$, with a warm stage maintained at $37^{\circ} \mathrm{C}$. A wet mount was made using a $5 \mu 1$ drop of semen $\left(2 \times 10^{6}\right.$ sperm $)$ placed directly 
on a microscope slide and covered by a cover slip. Sperm motility estimations were performed in 3 different microscopic fields for each semen sample. The mean of the 3 successive estimations was recorded as the final motility score.

For the sperm morphology assessment, at least 3 drops of semen were added to Eppendorf tubes, containing $1 \mathrm{ml}$ of Hancock's $(62.5 \mathrm{ml}$ formalin, $150 \mathrm{ml}$ sodium saline solution, $150 \mathrm{ml}$ buffer solution, and $500 \mathrm{ml}$ doubledistilled water) solution (Schafer and Holzmann 2000). One drop of this mixture was put on a microscope slide and covered with a cover slip. The percentage of abnormal sperm (detached heads, acrosomal aberrations, abnormal mid-pieces and tail defects) was recorded by counting a total of 200 spermatozoa under phase contrast microscopy ( $\times 1000$ magnification; oil immersion).

The sperm viability of the samples was assessed by means of the nigrosin-eosin staining (Evans and Maxwell 1987). The stain was prepared as eosin-Y $1.67 \mathrm{~g}$, nigrosin $10 \mathrm{~g}$, sodium citrate $2.9 \mathrm{~g}$, dissolved in $100 \mathrm{ml}$ distilled water. The sperm suspension smears were prepared by mixing a drop of the semen sample with 2 drops of the stain on a warm slide and spreading the stain with a second slide immediately. The viability was assessed by counting 200 cells under the phase-contrast microscope $(\times 1000$ magnification $)$. Sperm showing partial or complete purple colouring were considered non-viable and only sperm showing strict exclusion of the stain were considered to be alive.

The Hypoosmotic Swelling Test (HOST) was used as a complementary test to the viability assessment protocol to evaluate the functional integrity of the sperm plasma membrane. HOST relies on the resistance of the membrane to the loss of permeability barriers under stress conditions of stretching in a hypoosmotic medium (Buckett et al. 1997). Sperm cells with resistant membranes exhibited a swelling around the tail, such that the flagella became curled and the membrane maintained a swollen 'bubble' around the curled flagellum. The assay was performed by mixing $30 \mu 1$ of semen with a $300 \mu 1100 \mathrm{mOsm} / \mathrm{kg}$ hypoosmotic $(9 \mathrm{~g}$ fructose plus $4.9 \mathrm{~g}$ sodium citrate per litre of distilled water) solution (Revell and Mrode 1994). This mixture was incubated $\left(37{ }^{\circ} \mathrm{C}\right)$ for one hour; $0.2 \mathrm{ml}$ of the mixture was placed on a microscope slide and mounted with a cover slip and immediately evaluated ( $\times 400$ magnification) under the phase-contrast microscope. A total of 200 spermatozoa were counted in at least 5 different microscopic fields. The percentages of sperm with swollen and curled tails were then recorded.

Statistical analyses

The sperm evaluations were repeated 10 times and the results were expressed as the mean \pm S.E.M. Data were evaluated by analysis of variance (ANOVA), followed by the Duncan test to determine significant differences between the 12 experimental groups and the control group - with additives or no additive after the freezingthawing process for sperm characteristics using the SPSS/PC version 12.0 software (SPSS, Chicago). Differences with values of $P<0.05$ were considered to be statistically significant (Daniel 1991).

\section{Results}

The effects of different concentrations of GSSG on sperm characteristics following the freezing-thawing process are presented in Table 1. The anti-oxidant GSSH at $5 \mathrm{mM}$ had a significant $(P<0.001)$ effect in maintaining post-thaw sperm motility, sperm morphology, acrosome integrity, viability and membrane integrity when compared to the control group.

Table 1. Percentages of post-thawing motility, total abnormality, acrosome damage, viability and HOST in frozen-thawed ram spermatozoa (means \% $\%$ S.E.M)

\begin{tabular}{|l|c|c|c|c|c|}
\hline Groups & Motility & $\begin{array}{c}\text { Total } \\
\text { abnormality }\end{array}$ & $\begin{array}{c}\text { Acrosome } \\
\text { damage }\end{array}$ & Viability & HOST \\
\hline Control & $39.5 \pm 2.73 \mathrm{a}$ & $30.1 \pm 5.30 \mathrm{~b}$ & $13.4 \pm 2.32 \mathrm{~b}$ & $50.7 \pm 6.05 \mathrm{a}$ & $36.9 \pm 4.40 \mathrm{a}$ \\
\hline GSSG 5 mM & $60.6 \pm 1.63 \mathrm{~b}$ & $10.9 \pm 2.45 \mathrm{a}$ & $3.0 \pm 0.73 \mathrm{a}$ & $78.6 \pm 4.48 \mathrm{c}$ & $65.2 \pm 3.81 \mathrm{c}$ \\
\hline GSSG 10 mM & $48.0 \pm 2.81 \mathrm{a}$ & $12.3 \pm 2.50 \mathrm{a}$ & $10.7 \pm 1.69 \mathrm{ab}$ & $74.4 \pm 3.99 \mathrm{bc}$ & $44.8 \pm 6.04 \mathrm{ab}$ \\
\hline GSSG 20 mM & $44.5 \pm 2.12 \mathrm{a}$ & $19.8 \pm 3.21 \mathrm{a}$ & $8.4 \pm 3.41 \mathrm{ab}$ & $65.7 \pm 4.25 \mathrm{~b}$ & $49.3 \pm 3.72 \mathrm{~b}$ \\
\hline$P$ & $* * *$ & $* *$ & $* *$ & $*$ & $*$ \\
\hline
\end{tabular}

$(\mathrm{a}, \mathrm{b}, \mathrm{c})$ : Different letters within the same column showed significant differences among the groups $(* P<0.05$, ** $P<0.01, * * * P<0.001)$

The effect of the various concentrations of BSA on post-thawing sperm characteristics is set out in Table 2 . BSA $(20 \mathrm{mg} / \mathrm{ml})$ showed a more significant positive effect than other concentrations of BSA and the control group in protecting sperm characteristics during the freezing-thawing process of ram semen $(P<0.001)$. 
Table 2. Percentages of post-thawing motility, total abnormality, acrosome damage, viability and HOST in frozen-thawed ram spermatozoa (means $\% \pm$ S.E.M.)

\begin{tabular}{|l|c|c|c|c|c|}
\hline Groups & Motility & $\begin{array}{c}\text { Total } \\
\text { abnormality }\end{array}$ & $\begin{array}{c}\text { Acrosome } \\
\text { damage }\end{array}$ & Viability & HOST \\
\hline Control & $39.5 \pm 2.73 \mathrm{a}$ & $30.1 \pm 5.30 \mathrm{~b}$ & $13.4 \pm 2.32 \mathrm{~b}$ & $50.7 \pm 6.05 \mathrm{~b}$ & $36.9 \pm 4.40 \mathrm{a}$ \\
\hline BSA $5 \mathrm{mg} / \mathrm{ml}$ & $45.0 \pm 1.29 \mathrm{bc}$ & $15.2 \pm 2.70 \mathrm{a}$ & $9.4 \pm 2.95 \mathrm{ab}$ & $73.2 \pm 7.42 \mathrm{a}$ & $41.5 \pm 5.87 \mathrm{ab}$ \\
\hline BSA $10 \mathrm{mg} / \mathrm{ml}$ & $48.5 \pm 3.88 \mathrm{bc}$ & $17.1 \pm 3.93 \mathrm{a}$ & $8.6 \pm 2.30 \mathrm{ab}$ & $69.3 \pm 6.18 \mathrm{a}$ & $48.5 \pm 6.40 \mathrm{bc}$ \\
\hline BSA $20 \mathrm{mg} / \mathrm{ml}$ & $51.2 \pm 3.62 \mathrm{c}$ & $11.8 \pm 3.21 \mathrm{a}$ & $3.6 \pm 3.12 \mathrm{a}$ & $78.2 \pm 6.30 \mathrm{a}$ & $55.2 \pm 4.21 \mathrm{c}$ \\
\hline$P$ & $* *$ & $* * *$ & $*$ & $* *$ & $*$ \\
\hline
\end{tabular}

$(\mathrm{a}, \mathrm{b}, \mathrm{c})$ : Different letters within the same column showed significant differences among the groups $(* P<0.05$, ** $P<0.01, * * * P<0.001)$

Table 3. Percentages of post-thawing motility, total abnormality, acrosome damage, viability and HOST in frozen-thawed ram spermatozoa (means $\% \pm$ S.E.M.)

\begin{tabular}{|l|c|c|c|c|c|}
\hline Groups & Motility & $\begin{array}{c}\text { Total } \\
\text { abnormality }\end{array}$ & $\begin{array}{c}\text { Acrosome } \\
\text { damage }\end{array}$ & Viability & HOST \\
\hline Control & $39.5 \pm 2.73 \mathrm{a}$ & $30.1 \pm 5.30 \mathrm{c}$ & $13.4 \pm 2.32 \mathrm{~b}$ & $50.7 \pm 6.05 \mathrm{a}$ & $36.9 \pm 4.40 \mathrm{a}$ \\
\hline Cysteine $5 \mathrm{mM}$ & $45.0 \pm 3.42 \mathrm{a}$ & $19.2 \pm 4.76 \mathrm{~b}$ & $11.7 \pm 3.17 \mathrm{~b}$ & $70.5 \pm 5.29 \mathrm{~b}$ & $42.7 \pm 5.74 \mathrm{a}$ \\
\hline Cysteine $10 \mathrm{mM}$ & $59.0 \pm 4.35 \mathrm{~b}$ & $9.8 \pm 4.05 \mathrm{a}$ & $2.9 \pm 2.52 \mathrm{a}$ & $73.5 \pm 6.72 \mathrm{~b}$ & $40.7 \pm 4.74 \mathrm{a}$ \\
\hline Cysteine $20 \mathrm{mM}$ & $39.5 \pm 3.31 \mathrm{a}$ & $14.2 \pm 3.52 \mathrm{ab}$ & $8.1 \pm 4.21 \mathrm{ab}$ & $58.6 \pm 5.38 \mathrm{a}$ & $32.4 \pm 5.37 \mathrm{a}$ \\
\hline$P$ & $* * *$ & $* *$ & $* *$ & $* *$ & - \\
\hline
\end{tabular}

$(\mathrm{a}, \mathrm{b}, \mathrm{c})$ : Different letters within the same column showed significant differences among the groups $(* * P<0.01$, $* * * P<0.001)$

- : No significant difference $(P>0.05)$

The effect of the different concentrations of cysteine on the protection of sperm characteristics is set out in Table 3. Cysteine at $10 \mathrm{mM}$ had a significant $(P<0.001)$ effect on maintaining post-thawing sperm characteristics, when compared to the other treatments.

The effects different concentrations of lycopene on sperm characteristics following freezethawing process are set out in Table 4 . Lycopene at $800 \mu$ g exhibited significantly $(P<0.001)$ the best post-thawing spermatological indicators when compared to the other groups.

Table 4. Percentages of post-thawing motility, total abnormality, acrosome damage, viability and HOST in frozen-thawed ram spermatozoa (means $\% \pm$ S.E.M.)

\begin{tabular}{|l|c|c|c|c|c|}
\hline Groups & Motility & $\begin{array}{c}\text { Total } \\
\text { abnormality }\end{array}$ & $\begin{array}{c}\text { Acrosome } \\
\text { damage }\end{array}$ & Viability & HOST \\
\hline Control & $39.5 \pm 2.73 \mathrm{a}$ & $30.1 \pm 5.30 \mathrm{~b}$ & $13.4 \pm 2.32 \mathrm{a}$ & $50.7 \pm 6.05 \mathrm{~b}$ & $36.9 \pm 4.40 \mathrm{a}$ \\
\hline Lycopene $800 \mu \mathrm{g}$ & $57.2 \pm 2.91 \mathrm{~b}$ & $16.3 \pm 2.53 \mathrm{a}$ & $7.3 \pm 2.61 \mathrm{a}$ & $70.5 \pm 6.91 \mathrm{c}$ & $49.1 \pm 3.18 \mathrm{~b}$ \\
\hline Lycopene $1600 \mu \mathrm{g}$ & $46.5 \pm 3.00 \mathrm{ab}$ & $25.3 \pm 5.04 \mathrm{ab}$ & $12.6 \pm 4.62 \mathrm{a}$ & $61.5 \pm 6.29 \mathrm{ac}$ & $55.1 \pm 6.12 \mathrm{~b}$ \\
\hline Lycopene $3200 \mu \mathrm{g}$ & $33.0 \pm 3.09 \mathrm{a}$ & $26.2 \pm 5.87 \mathrm{ab}$ & $11.5 \pm 2.68 \mathrm{a}$ & $39.4 \pm 6.16 \mathrm{a}$ & $29.16 \pm 3.72 \mathrm{a}$ \\
\hline$P$ & $* * *$ & $* *$ & - & $* *$ & $* * *$ \\
\hline
\end{tabular}

$(\mathrm{a}, \mathrm{b}, \mathrm{c})$ : Different letters within the same column showed significant differences among the groups $(* * P<0.001$, $* * * P<0.01)$

- : No significant difference $(P>0.05)$

\section{Discussion}

The sperm plasma membrane is rich in polyunsaturated fatty acids and is therefore susceptible to peroxidative damage with consequent loss of membrane integrity, decreased sperm motility, and eventually loss in fertility, resulting from reactive oxygen species 
during aerobic incubation (Alvarez et al. 1987). Therefore, free radicals must be eliminated by supplementation with antioxidants such as GSH, cysteamine and taurine during the freezing-thawing or liquid storage of semen (Bucak and Tekin 2007 in press; Bucak et al. 2007).

Cryopreservation alters the membrane sulfhydryl status of spermatozoa. GSSG reduces the mobility of sulfhydryl-containing proteins in the sperm membrane. Sulfhydryl groups are under redox control and a change in the redox status of the membrane can be linked to the ROS production that occurs during cooling and freezing-thawing of spermatozoa (Mazur et al. 2000). The GSH/GSSG pair plays important roles both as a redox sensor and protector against ROS induced damages in many cell types (Halliwell and Gutteridge 1998).

Glutathione peroxidase, a selenium-containing antioxidant enzyme with glutathione, as the electron donor, removes peroxyl (ROO.) radicals from various peroxides including $\mathrm{H} 2 \mathrm{O} 2$. Glutathione reductase then regenerates reduced GSH from GSSG as shown in the following equation:

$2 \mathrm{GSH}+\mathrm{H}_{2} \mathrm{O}_{2}$ peroxidase-(Se) $\mathrm{GSSG}+2 \mathrm{H}_{2} \mathrm{O}$

GSSG + NÂDPH + H+ reductase $2 \mathrm{GSH}+\mathrm{NADP}+($ Calvin et al. 1981)

Cryopreservation of spermatozoa reduced the GSH level 5-fold, without increasing the GSSG level, which could suggest that the GSH content of spermatozoa may be transported out of the sperm cells (Bilodeau et al. 2000). Therefore, upon addition to the extender, GSSG partially prevents the loss of sperm motility after a freezing/thawing cycle, whereas GSH does not. GSSG, but not GSH, prevents increase in the mobility of sulfhydryl containing proteins due to the freezing/thawing of spermatozoa (Chatterjee et al. 2001). GSSG also interacts with two vicinal free cysteine residues of the active site in protein tyrosine phosphatases and inactivates these enzymes (Gabitta et al. 2000). Such a mechanism could explain the positive effects exerted by GSSG (Hammerstedt et al. 1990).

In the present study, it was observed that post-thawing in vitro results from whole concentrations of GSSG were much better than the control group. The concentration of $5 \mathrm{mM} \mathrm{GSSG}$ was determined to exert the best protective effect on post-thawing sperm motility, sperm morphology, acrosome integrity, viability and membrane integrity in ram semen. Higher concentrations of GSSG $(10$ or $20 \mathrm{mM})$ may have exhibited negative or toxic effect on post-thawing spermatological indicators when compared to the $5 \mathrm{mM}$ concentration of GSSG.

BSA is known to eliminate free radicals generated by oxidative reactions, and therefore to protect the membrane integrity of sperm cells from lipid peroxidation during the semen freezing process (Lewis et al. 1997). In our investigation, various concentrations of BSA were observed to improve post-thawing sperm motility and viability, and to protect acrosome and membrane integrity, but the best results were obtained from $20 \mathrm{mg} / \mathrm{ml}$ of BSA. It can be concluded that concentrations lower than $20 \mathrm{mg} / \mathrm{ml}$ of BSA are not sufficient to protect sperm cells from lipid peroxidation. Post-thawing sperm motility $(51.2 \%)$, morphologic sperm abnormalities (11.8\%), acrosome damage (3.6\%), and viable sperm (78.2\%) were determined for $20 \mathrm{mg} / \mathrm{ml} \mathrm{BSA}$ in our study, which are close to the findings of Matsuoka et al. (2006).

Thiol compounds, such as cysteine, are precursors of intracellular glutathione biosynthesis, and cysteine protects sperm cells from toxic oxygen metabolites causing lipid peroxidation of sperm plasma membranes under in vitro conditions (Meister and Tate 1976). Funahashi and Sano (2005) reported that a semen extender with $5 \mathrm{mM}$ cysteine improved the viability and membrane integrity of boar sperm cells during liquid storage. On the contrary, in the current study, the best post-thawing spermatological indicators were obtained from goat semen frozen with $5 \mathrm{mM}$ cysteine. 
Carotenoids such as beta-carotene and lycopene are also important components of antioxidant defense (Gupta and Kumar 2002). Beta-carotenes protect the plasma membrane against lipid peroxidation (Di Mascio et al. 1989). In this study, the effect of lycopene was similar to results obtained by other researchers, who reported that epididiymal sperm characteristics were protected in rat testes treated by lycopene (Ateşşahin et al. 2006) and structural and functional damage in the testicular tissue and sperm quality of rats caused by oxidative stress were prevented by lycopene supplementation (Türk et al. 2006). However, according to our findings, a lycopene concentration of $3200 \mu \mathrm{g}$ was determined to lead to deleterious effects on spermatological indicators including a decline in sperm motility, and an increase in sperm abnormality, acrosome damage and dead sperm.

In conclusion, this study demonstrated that supplementation with antioxidants of semen diluents, depending on various concentrations, during semen cryopreservation attempts, may exert beneficial effects on the quality of the freezing-thawing of ram semen. This study has shown that many aspects of sperm protection, e.g. sperm motility, viability and membrane stabilisation of sperm cells during relative cryopreservation, are of prime importance, the antioxidants GSSG $(5 \mathrm{mM})$, BSA $(20 \mathrm{mg} / \mathrm{ml})$, cysteine $(10 \mathrm{mM})$ and lycopene $(800 \mu \mathrm{g})$ provided a near-optimal concentration for improved sperm survival during the freezing-thawing process. The results of this study therefore provide a new approach to the cryopreservation of sperm from rams of different breeds, and so contribute to the improvement of these breeds for the world sheep industry. Further studies are necessary to obtain results to confirm present findings.

\section{Účinek oxidovaného glutathionu, bovinního sérového albuminu, cysteinu a lycopenu na kvalitu rozmrazeného semene beranů}

Volné radikály se účastní peroxidace lipidů stejně tak jako poškozování DNA a membrány spermií, což může vést ke snížení motility spermií nebo smrti buňky. Rovnováha mezi produkcí radikálů a jejich zneškodňováním může být důležitým faktorem pro životaschopnost spermií a jejich funkci před, během a po kryokonzervaci. Cílem této studie bylo zjistit vliv přídavku antioxidantů (oxidovaný glutathion (GSSG), bovinního sérového albuminu (BSA), cysteinu a lycopenu) do konzervačního média na vlastnosti spermatu po rozmražení, jako jsou např́klad motilita, morfologie, integrita akrozomu, životaschopnost a integrita membrány. Celkový počet 42 ejakulátů byl odebrán na umělou vagínu od čtyř beranů plemene Akkaraman a 10 párových vzorků ejakulátů bylo zředěno Tris pufrem s přísadami. Vzorky zréeděné Tris pufrem bez přísad sloužily jako kontrola. Po rozmrazení se ukázalo, že nejlepší účinek ze všech koncentrací ve vzorcích a kontrolách na vlastnosti semene měly GSSG $(5 \mathrm{mM})$, BSA $\left(20 \mathrm{mg} \cdot \mathrm{ml}^{-1}\right)$, cystein $(10 \mathrm{mM})$ a lycopene $(800 \mu \mathrm{g})$ $(P<0,001)$. Četné aspekty ochrany spermií, jako např. jejich motilita, životaschopnost a stabilizace membrány spermií během kryokonzervace, jsou klíčovými faktory pro uchování funkce spermií. Výsledky této studie předkládají nový přístup ke kryokonzervaci spermatu beranů a př́buzných plemen a tak přispívají ke zlepšení těchto plemen pro světovou produkci ovcí.

\section{Acknowledgement}

The authors thank Dr. Safa Gürcan for the statistical analyses, and the staff of the Department of Reproduction and Artificial Insemination for their technical assistance.

\section{References}

AGARWAL A, PRAHAKARAN SA, SAID TM 2005: Prevention of oxidative stress injury to sperm. J Androl 26: $653-60$

ALVAREZ JG, TOUCHSTONE JC, BLASCO L, STOREY BT 1987: Spontaneous lipid peroxidation and production of hydrogen peroxide and superoxide in human spermatozoa: superoxide dismutase as a major enzyme protectant against oxygen toxicity. J Androl 23: 338-348 
ATEŞŞAHIN A, TÜRK G, KARAHAN İ, YILMAZ S, ÇERIBAŞI AO, BULMUŞ Ö 2006: Lycopene prevents adriamycin-induced testicular toxicity in rats. Fertil Steril 85: 1216-1222

BAUMBER J, BALL BA, GRAVANCE CG, MEDINA V, DAVIES-MOREL MCG 2000: The effect of reactive oxygen species on equine sperm motility, viability, acrosomal integrity, mitochondrial membrane potential and membrane lipid peroxidation. J Androl 21: 895-902

BAUMBER J, BALL BA, LINFOR JJ 2005: Assessment of the cryopreservation of equine spermatozoa in the presence of enzyme scavengers and antioxidants. Am J Vet Res 66: 772-779

BERNARD O, BALASUBRAMANIAN KA 1995: Effect of oxidized glutathione on intestinal mitochondria and brush border membrane. Int J Biochem Cell Biol 27: 589-595

BILODEAU JF, CHATTERJEE S, SIRARD MA, GAGNON C 2000: Levels of antioxidant defenses are decreased in bovine spermatozoa after a cycle of freezing and thawing. Mol Reprod Dev 5:282-288

BUCAK MN, TEKIN N 2007: Protective effect of taurine, glutathione and trehalose on the liquid storage of ram semen. Small Ruminant Res (in press)

BUCAK MN, ATEŞŞAHIN A, VARIŞLI Ö, YÜCE A, TEKİN N, AKÇAY A 2007: The influence of trehalose, taurine, cysteamine and hyaluronanon ram semen: Microscopic and oxidative stress parameters after freezethawing process. Theriogenology 67: 1060-1067

BUCKETT WM, LUCKAS MJ, AIRD IA, FARQUHARSON RG, KINGSLAND CR, LEWIS-JONES DI 1997: The hypoosmotic swelling test in recurrent miscarriage. Fertil Steril 68: 506-509

CALVIN HI, COOPER GW, WALLACE EW 1981: Evidence that selenium in rat sperm is associated with a cysteine-rich structural proteins of the mitochondrial capsule. Gamete Res 4: 139-145

CHATTERJEE S, DE LAMIRANDE E, GAGNON C 2001: Cryopreservation alters membrane sulphydryl status of bull spermatozoa: protection by oxidized glutathione. Mol Reprod Dev 60: 498-506

DANIEL WW 1991: Analysis of Variance. In: DANIEL WW (Ed.), Biostatistic: A Foundation for Analysis in the Health Sciences. John Wiley \& Sons, Hoboken, pp. 274-320

DI MASCIO P, KAISER S, SIES H 1989: Lycopene as the most efficient biological carotenoid singlet oxygen quencher. Arch Biochem Biophys 274: 532-538

EVANS G, MAXWELL WMC 1987: Handling and examination semen. In: MAXWELL WMC (Ed.), Salamon's Artificial Insemination of Sheep and Goat, Butterworths, Sydney, pp. 93-106

FUNAHASHI H, SANO T 2005: Select antioxidants improve the function of extended boar semen stored at 10 ${ }^{\circ} \mathrm{C}$. Theriogenology 6: 1605-1616

GABITTA SP, ROBINSON KA, STEWART C A, FLOYD RA, HENSLEY K 2000: Redox regulatory mechanism of cellular signal transduction. Arch Biochem Biophys 376: 1-13

GUPTA NP, KUMAR R 2002: Lycopene therapy in idiopathic male infertility - a preliminary report. Int Urol Nephrol 34: 369-372

HALLIWELL B, GUTTERIDGE JMC 1998: Antioxidant defences. In: HALLIWELL B, GUTTERIDGE JMC (Eds), Free radicals in biology and medicine. Oxford, University Press (London), pp. 155-158

HAMMERSTEDT RH, GRAHAM JK, NOLAN JP 1990: Cryopreservation of mammalian sperm: what we ask them to survive? J Androl 11: 73-88

KING ME, MCKELVEY WAC, DINGWALL WS, MATTHEWS KP, GEBBIE FE, MYLNE MJA 2004: Lambing rates and litter sizes following intrauterine or cervical insemination of frozen/thawed semen with or without oxytocin administration. Theriogenology 62: 236-244

LUBERDA Z 2005. The role of glutathione in mammalian gametes. Reprod Biol 5: 5-17

MATSUOKA T, IMAI H, KOHNO H, FUKUI Y 2006: Effects of bovine serum albumine and trehalose in semen diluents for improvement of frozen-thawed ram spermatozoa. J Reprod Develop 52: 675-83

MAXWELL WMC, WATSON PF 1996: Recent progress in the preservation of ram semen. Anim Reprod Sci 42: $55-65$

MAXWELL WMC, STOJANOV T 1996: Liquid storage of ram semen in the absence or presence of some antioxidants. Reprod Fert Develop 32: 353-360

MAZUR P, KATKOV II, KATKOVA N, CRITSER JK 2000: The enhancement of the ability of mouse sperm to survive freezing and thawing by the use of high concentrations of glycerol and the presence of an Escherichia coli membrane preparation (Oxyrase) to lower the oxygen concentration. Cryobiology 40: 187-209

MEISTER A, TATE SS 1976: Glutathione and related gamma-glutamyl compounds: biosynthesis and utilization. Annu Rev Biochem 45: 559-604

OLLERO M, GARCIA-LÓPEZ N, CEBRIÁN-PÉREZ JA, MUIÑO-BLANCO T 1996: Viability of ram spermatozoa in relation to the abstinence period and successive ejaculations. Int J Androl 19: 287-292

PAULENZ H, SÖDERQUIST L, PÉREZ-PÉ R, BERG KA 2002: Effect of different extenders and storage temperatures on sperm viability of liquid ram semen. Theriogenology 57: 823-836

REVELL G, MRODE RA 1994: An osmotic resistance test for bovine semen. Anim Reprod Sci 36: 77-86

SALAMON S, MAXWELL WMC 1995: Frozen storage of ram semen. II. Causes of low fertility after cervical insemination and methods of improvement. Anim Reprod Sci 38: 1-36

SALVADOR I, YANIZ J, VIUDES-DE-CASTRO MP, GOMEZ EA, SILVESTRE MA 2006: Effect of solid storage on caprine semen conservation at $5{ }^{\circ} \mathrm{C}$. Theriogenology 64: $252-260$ 
SANOCKA DM, KURPISZ M 2004: Reactive oxygen species and sperm cells. Reprod Biol Endocrinol 2: 12-18 SCHAFER S, HOLZMANN A 2000: The use of transmigration and Spermac ${ }^{\mathrm{TM}}$ stain to evaluate epididymal cat spermatozoa. Anim Reprod Sci 59: 201-211

SINHA MP, SINHA AK, SINGH BK, PRASAD PL 1996: The effect of glutathione on the motility, enzyme leakage and fertility of frozen goat semen. Theriogenology 41: 237-243

SMITH JT, MAYER DT 1955: Evaluation of sperm concentration by the hemocytometer method. Fertil Steril 6: $271-275$

SZCZESNIAK-FABIANCZYK B, BOCHENEK M, SMORAG Z, SILVESTRE MA 2006: Effect of antioxidants added to boar semen extender on the semen survival time and sperm chromatin structure. Reprod Biol 3: $81-87$

TÜRK G, ATEŞŞAHIN A, SÖNMEZ M, YÜCE A, ÇERİBAŞI AO 2006: Lycopene protects against cyclosporine A-induced testicular toxicity in rats. Theriogenology 67: 778-785

UYSAL O, KORKMAZ T, TOSUN H 2005. Effect of bovine serum albumine on freezing of canine semen. Indian Vet J 82: 97-98 